\title{
Logistics FDI in Italy: integration strategies and motivations
}

\author{
Elena Maggi • Ilaria Mariotti
}

Received: 23 July 2009 / Accepted: 1 February 2010 / Published online: 5 March 2010

(C) The Author(s) 2010. This article is published with open access at Springerlink.com

\begin{abstract}
Background and aim The aim of the paper is to investigate the integration strategies (vertical, horizontal and conglomerate) undertaken by foreign logistics multinational enterprises (MNE) in Italy, and analyze the related motivations.

Methods The empirical analysis consists of descriptive statistics, which makes use of the LogINT database, monitoring inward logistics foreign direct investments (FDI) in Italy in 2000-2008, and of additional information on the foreign logistics MNE's integration strategies.

Result It results that inward logistics FDI are mainly horizontal, that is they operate in the same parent company's sub-industry, and are mainly driven by market power' and economies of scale' increase. Vertical integrations, which are in a logistics sub-industry differing from the MNE's one, are driven by competitive considerations, by the need to reach economies of scope and reduce transaction costs. The conglomerate integrations, which are mainly undertaken by financial and real estate investors and manufacturing firms, are motivated by the need to achieve economies of scale and reduce transaction costs.

Conclusion The empirical analysis has showed that the motivations driving inward FDI are often multiple and differ according to the peculiarities of the sub-industry.
\end{abstract}

\footnotetext{
E. Maggi $(\bowtie)$

Faculty of Economics, Department SEGeS,

Università degli Studi del Molise,

via De Sanctis,

86100 Campobasso, Italy

e-mail: elena.maggi@unimol.it

I. Mariotti

Politecnico di Milano, DiAP,

piazza L. da Vinci, 32,

20133 Milan, Italy
}

Keywords Logistics industry · Integration strategies · FDI · MNE $\cdot$ M\&A $\cdot$ Greenfield investments

\section{Introduction}

The internationalisation of the logistics industry has massively increased in the last three decades. Given this rapid growth, fully understanding the determinants and implications of the phenomenon has been high on the agenda for both policy makers and academics [24]. There seems to be a rationale in expanding the portfolio of logistics services or widening the geographical presence of the firm through inward foreign direct investments (FDI), that take the form of greenfield (new plant) and brownfield (merger and acquisition-M\&A), or through the so called strategic alliances [30].

In the last years, the growth rate of FDI in the utilities (energy, gas and water), logistics and communications has more than tripled [33] and outward FDI in the logistics industry equals to $26 \%$ of the service total [27]. Merger and acquisition activity in logistics services has originated in the U.S. in the early 1980s and has interested Europe a few years later. Besides, a similar process began in the Far East in the middle of the 1980s, led by Japanese logistics firms [30]. Quite recently, the European transport market has attracted investors from the Asian Newly Industrialised countries, a phenomenon called "the Mega-carrier Race" [8].

Recent examples of these investments are: DHL Express acquired $49 \%$ of the American airline company Polar Air Cargo Worldwide; DHL Exel acquired the Chinese Sinotrans Air Transport; the Japanese shipping group NYK invested in the new airline company Jett Airlines Cargo from Singapore [for a detailed overview 
see 15]. Besides, large foreign logistics suppliers dominate the Italian market, i.e. Eurokai, TPG-TNT, Deutsche Post and A.P. Moller-Maersk.

If we focus on inward FDI (greenfield and M\&A) and look at the investment industry, we can distinguish three investment strategies: horizontal, vertical and conglomerate integrations. In case of horizontal integration, the investment is carried out in the same industry of the parent multinational enterprise (MNE). When vertical integration takes place, the MNE invests in different logistics subindustries. Finally, a conglomerate integration occurs when the investment in a logistics activity is carried out by a nonlogistics MNE (i.e. a manufacturing MNE).

The three strategies are driven by specific motivations, going from "increasing market power" to "reducing transaction costs" [for a review, see among the others 9, 21].

As concerns Italy, that is the country of interest of the present paper, in the last decade the logistics industry has been increasingly interested by inward FDI, which are concentrated in the supply of integrated and intermodal services or other higher value added services than the pure goods and passengers transport. In this paper we use a wide definition of logistics industry as the ensemble of the firms offering all the services useful for the movements of goods along the supply chain and passengers from an origin to a final destination. More precisely, it comprises both Logistics Services Providers (LSP), offering single services, on a stand-alone basis (transportation, warehousing, handling, etc.) and Third-Party Logistics (3PLs) or Fourth Party Logistics (4PLs) Providers or Integrated Logistics Providers, supplying different services in a integrated way. To do so, we refer to all the codes included in 2002 NACE industry "I" "Transport, storage and communication", with the exception of 64.11 (national post activities) and 64.2 (telecommunications) $)^{1}$.

The integration strategies are a relatively unexplored area in logistics research. The present paper extends the existing literature on the integration strategies undertaken by MNE investing in foreign markets, by exploring the motivations behind them and focusing on the logistics service industry in Italy. The data used come from the LogINT database, developed by the Laboratory of Economics, Logistics and Territory of DiAP-Politecnico di Milano, and covers the period 2000-2008. Additional qualitative data about the motivations behind the integration strategies, undertaken by the foreign logistics MNE, have been collected from the logistics magazines and the companies' web sites.

\footnotetext{
${ }^{1}$ We refer to the NACE 2002 classification instead of the more recent 2008 because of lack of data.
}

The paper is structured into five sections. The introduction is followed by a literature review on the entry modes, the integration strategies, and the motivations behind them. Besides, the research hypotheses to be empirically tested are presented. A description of inward logistics FDI in Italy (stock, sub-industry, origin and destination areas) is presented in section three. Section 4 focuses on the integration strategies concerning the Italian logistics industry, analysing them by sub-industry and area of origin and destination and identifying the feasible motivations driving them. Conclusions and further research questions conclude the paper.

\section{Literature review}

\subsection{Entry modes and integration strategies}

The choice of entry mode is an important part of a firm's foreign investment strategy [1]. Firms are not only concerned about which foreign markets to enter, and which activities to perform in those markets, but how to enter: whether by export, licensing and FDI [7].

There are two main strands of literature analysing firms' entry modes [for a detailed overview see 37]: the first discusses the choice between broad international market entry modes such as trade, alliances and FDI [1, 5, 11, 25]; the second focuses on the choice of undertaking a FDI, and specifically choosing between greenfield and brownfield investments [e.g. 7, 17].

The interest of the present paper is limited to the FDI entry mode, defined as investment involving ownership, and conferring effective management control. Other internationalisation forms, i.e. exporting, strategic alliances, do not constitute FDI and, therefore, are beyond the scope of this study. Specifically, we focus on two entry modes: greenfield investments and brownfield investments (M\&A). Greenfield investment concerns full ownership and consists of opening up of a new plant, while brownfield investment, that is M\&A, denotes the purchase of a controlling interest in a local firm. In particular, a merger consists in a mutual agreement of the management of two or more companies to form a new joint legal entity through the exchange of shares or other funds. An acquisition takes place when the management of one company makes a direct offer to the shareholders of another company to acquire controlling interest of this firm [36].

Three strands of literature focus on the typologies of FDI according to the investment industry: the business and administration economic literature ${ }^{2}$ [among the others, 7 ,

\footnotetext{
${ }^{2}$ The studies belonging to the strategic management literature focus on the acquisition "relatedness", which refers to the degree of correspondence between an acquirer and its target [see, among the others, 22].
} 
$21,30]$, the international economic literature [among the others, 1, 3, 5, 11, 24] and the transportation economic literature $[6,9,10,12-16,31,32,34]$. These studies mainly refer to the M\&A operations classifying them into: (i) horizontal M\&A; (ii) non-horizontal M\&A, which comprises vertical $M \& A$ and conglomerate $M \& A$.

In horizontal M\&A, both companies operate in the same industry and on the same industry level. Vertical M\&A involve firms that operate in different stages of the same industry. Instead, firms in conglomerate M\&A do not operate in the same business industry at all (Table 1). According to a narrower definition, proposed by Hijzen et al. [24], horizontal M\&A concerns the activity taking place within the same 4-digit US SIC industry. It is thereby assumed that 4-digit industries represent homogenous groupings of firms. As the authors stress, however, this classification may in some cases be too restrictive; specifically, some transactions across 4 digit industries may still involve horizontal mergers, in particular when multi-product firms are prevalent. This could only be addressed adequately if data were available on all products produced by a firm.

The literature on integration strategies in logistics is however still in its infancy and mainly refers to horizontal M\&A [32, 34 for maritime shipping; 12, 31 for airline industry; 6,9 for $3 \mathrm{PLs}]$.

\subsection{Motivations and hypotheses to be tested}

The literature extensively studies the motives behind the choice to undertake a foreign direct investment, while less attention has been placed on the determinants for horizontal, vertical and conglomerate integrations.

The literature stresses that acquisitions offer the fastest means of building a sizable presence in a foreign market, yet they are fraught with risks of overpayment, inability to fully assess the value of acquired assets, and postacquisition challenges including cross-cultural integration. Greenfield investments offer the greatest control over the local affiliate, yet often require the longest time to establish, and the greatest contribution of know-how [7].

From the knowledge-based perspective, greenfield investment may be the most efficient entry mode when a firm transfers knowledge from home country to foreign affiliate [7]. Acquisition may be preferred when the firm enters a foreign country in order to tap local skills and resources.

Referring to the business and administration economic literature, the international economic literature and the transportation economic literature, we can summarised the main motivations, driving horizontal, vertical and conglomerate integrations, as follows [among the others, 3, 9, 21, 24, 30, 35]:

\section{Competitive considerations}

1a) Increasing market or political power

1b) Defending market share

\section{Efficiency considerations}

2a) Scale economies

2b) Scope economies

2c) Elimination of transaction costs

Other considerations

3a) Regulation

3b) Access to technologies

As concerns competitive considerations, firms can undertake greenfield or M\&A to increase their market or political power or to acquire new markets (1a). Especially in horizontal integrations, the desire to achieve or strengthen monopoly power seems to have played a prominent role (Table 2). New market access is mostly achieved through M\&A, which, in comparison to greenfield investments, allow the firm to gain a quicker access.

Similarly the horizontal integrations can be motivated by a defensive strategy (1b) which may consists of: (i) preventing being taken-over; (ii) preventing the target from being taken over by others; (iii) avoiding other merged entities in the industry from becoming too strong [19]. Referring to the logistics sector, that is the goal of the present paper, we can state that the competitive considerations play a crucial role within the horizontal strategies and a relevant role in the vertical ones (Table 2).

Next to competitive considerations, firms opt for FDI in search of efficiency gains, i.e.:

(2a) Economies of scale: firms can enjoy lower average costs when operating at a combined size that is larger

Table 1 Integration strategies

\begin{tabular}{ll}
\hline Typology & Description \\
\hline Horizontal & Both companies operate in the same industry \\
Vertical & The firms operate in different stages of the same industry \\
Conglomerate & The companies operate in different industries \\
\hline
\end{tabular}


than when operating separately. These cost economies arise typically from sharing common inputs and spreading fixed costs over a larger output. Economies of scale in production are the most obvious motivation and are more likely to be achieved following horizontal integrations (Table 2). In a logistics context, horizontal integration increases the company's productivity for core activities (e.g. optimising vehicle capacity utilization, reducing empty mileage, better usage of storage facilities, etc.); it reduces the costs of non-core activities (e.g. organizing safety trainings, joint fuel facilities, etc.); and it cuts purchasing, marketing and R\&D costs (e.g. vehicles, onboard computers, fuel, etc.) $[9,34]$.

(2b) Economies of scope: the combination of complementary skills can result in a more efficient way of producing. Economies of scope arise whenever the total cost of producing two different goods or services jointly is lower than producing each of the goods separately (vertical integrations). Within a logistics context, investing MNE can specialize while at the same time broadening their services through vertical integrations (Table 2); they can offer better quality of service at lower costs (e.g. in terms of speed, frequency of deliveries, geographical coverage, reliability of delivery times etc.) [6,9].

(2c) Elimination of transaction costs $^{3}$ : an investment involving vertical integration may reduce costs by replacing market transactions between firms, by planning and coordination among firms [18] (Table 2). In case of M\&A, the merged firm will have access to better information at lower costs, since it is easier to monitor activity within a firm than to obtain information about the activities of a separate firm. The transaction costs' reduction results from small number bargaining, enhancing the competitive position or market power of the partners, and meeting the partner's request for organizational knowledge and learning [26]. In the logistics case, it can also be relevant within the conglomerate integration, when the investment is made by a manufacturing firm in order to cut the transaction costs with its logistics suppliers. Firms decide to undertake FDI for other considerations, too, such as regulation (3a) and access to technologies (3b).

(3a) Because of regulatory reasons, firms may have an incentive to merge even if there is no fundamental economic efficiency involved. A change in the regulatory rules of an industry in a country, such as the liberalisation of a market previous regulated by a

\footnotetext{
${ }^{3}$ There is an extensive literature on transaction costs' reduction due to FDI [among the others, 2, 23].
}

public monopoly, can attract MNE from other countries. Tax savings could result when a lossmaking firm merges with a profitable one. Furthermore, the regulated firms might want to diversify into an unregulated market in order to shift profits from the regulated market into the unregulated one [35]. We expect regulation to be relevant in the horizontal and vertical integration strategies, undertaken in those sub-industries, which have experienced in the last decade a liberalisation process (Table 2).

(3b) As concerns access to technologies, a firm looking to increase its scope of operations into new markets, characterised by advanced technologies, considers internal growth versus external growth through M\&A. In this perspective, M\&A in comparison to internal growth offers the advantage to the firm of providing a quick access to new technologies using proven know-how, rather than to set up 'ex-novo' new activities (greenfield) or do own R\&D. As concerns the logistics industry, it is well known that the vast majority of logistics firms are small and medium sized enterprises (SME), which, by definition, tend to lag behind in implementation of information and communication technology (ICT) systems [20]. The study carried out by Cruijssen et al. [9] shows that ICT is mainly an issue for horizontal integrations of a medium intensity. Low intensity initiatives often do not require specific ICT investments and high intensity initiatives generate sufficient revenue to pay back the required ICT investments. Therefore, we can state that access to technologies is one of the main motives driving horizontal logistics integrations, but it can be also relevant in the other two strategies (Table 2).

The concise description of the motives behind the integration strategies has showed that each integration often combines multiple motives. By focusing on the logistics sector, we can draw the following hypotheses concerning the relationship between integration strategies and motives (Table 2).

\section{Inward logistics FDI in Italy}

The structural patterns of the Italian logistics industry and, specifically, the significant pulverization of the firms, have attracted international global players, which mainly supply integrated and high value added services. In Italy, SME predominate the scenario and this structural pattern does not foster the development of know how, human and financing resources. Besides, SME do not develop the specific necessary innovations to offer a multifaceted range of services, able to satisfy the customers' demand. 
Table 2 Hypotheses to be tested

\begin{tabular}{llll}
\hline Motivation & \multicolumn{2}{l}{ Integration strategies } & \\
\cline { 2 - 4 } & Horizontal & Vertical & Conglomerate \\
\hline Competitive considerations & & & \\
1a) Increasing market or political power & $\mathrm{c}$ & $\mathrm{b}$ & $\mathrm{a}$ \\
1b) Defending market share & $\mathrm{c}$ & $\mathrm{b}$ & $\mathrm{a}$ \\
Efficiency considerations & & $\mathrm{a}$ & $\mathrm{a}$ \\
2a) Economies of scale & $\mathrm{c}$ & $\mathrm{c}$ & $\mathrm{a}$ \\
2b) Economies of scope & $\mathrm{a}$ & $\mathrm{c}$ & $\mathrm{b}$ \\
2c) Elimination of transaction costs & $\mathrm{a}$ & & $\mathrm{a}$ \\
Other considerations & & $\mathrm{b}$ & $\mathrm{b}$ \\
3a) Regulation & $\mathrm{b}$ & $\mathrm{b}$ & \\
3b) Access to technologies & $\mathrm{c}$ & & \\
\hline
\end{tabular}

${ }^{\mathrm{a}}$ not relevant; ${ }^{\mathrm{b}}$ relevant;

${ }^{\mathrm{c}}$ extremely relevant remaining 31\%: land transport predominates (17\%), air transport $(6.5 \%)$, sea transport $(4.5 \%)$ and rail transport (3\%) follow.

As concerns origin and destination areas, the patterns of inward logistics FDI confirm those of the manufacturing industry [27]. Italy attracts FDI mainly from western Europe (71\%), North America (11.8\%), Asia (8.8\%) and Middle East (2.3\%). The MNE investing in Italy mainly belong to industrialised countries like Germany (19\%), France (12\%), UK (10\%), USA (10\%) and The Netherlands (7\%).

Foreign FDI are mainly located in the North West (56.1\%), "core" of the Italian logistics; follow the Centre (19\%) and the North East (17.4\%). South and Islands register the $7.5 \%$ of the total. In particular, Lombardy region, in the North West, attracts $40 \%$ of the investments and is followed by Lazio (12\%), Liguria (10\%), Veneto (7\%), Emilia Romagna (7\%) and Piedmont (6\%). Among the southern regions, we find Campania (3\%) and Calabria $(1 \%)$. This trend confirms that the logistics industry is strongly demand driven, i.e. it is settled where the manufacturing customers are located.

\section{Testing the hypotheses: integration strategies of inward logistics FDI in Italy}

\footnotetext{
${ }^{4}$ The LogINT database, developed by the Laboratory of Economics, Logistics and Territory of DiAP-Politecnico di Milano, with the collaboration of the University of Molise, is updated every year and collects data on inward and outward FDI in the logistics industry since 2000. The sources of the database are numerous: Reprint databank of the Italian FDI (developed by the Department of Management and Engineering of the Politecnico di Milano and sponsored by the Italian Trade Institute-ICE), newspaper and magazines on the logistics industry, direct interviews to logistics MNE, etc.

${ }^{5}$ Actually, the NACE 63.40.2 code is called "other supporting and auxiliary transport services", but it comprises a large number of firms offering integrated services and intermodal transport which doesn't find alternative location in other specific voices of the NACE classification.
}

\subsection{Integration strategies by investment industries}

Referring to the literature review, the Italian FDI undertaken by the 274 logistics MNE have been classified into the three categories above described (Table 1): (i) horizontal strategy, when the investment has been made in the same logistics sub-industry of the parent company; (ii) vertical strategy, when the investment concerns a different logistics sub-industry; (iii) conglomerate strategy, when the MNE comes from an industry totally different than the logistics 
Fig. 1 Inward Logistics FDI in Italy, by investment sub-industry

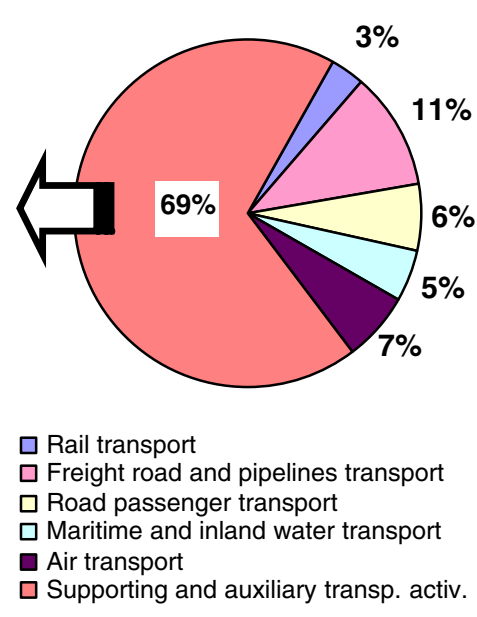

one. The industrial classification refers to the 2002 NACE codes $^{6}$ and to the information on the supplied services, provided by the web-sites of the foreign MNE and their Italian affiliates, or by the specialised logistics newspapers and magazines.

Reflecting a global trend [15], the FDI are mainly of horizontal type $(60 \%)$, while conglomerate and vertical strategies move respectively the $25 \%$ and the $15 \%$ of the investments (Fig. 2). This means, as Carbone and Stone [6] argue, that the increasing global competition has forced the logistics operators to concentrate in their core business, consolidating their market position.

The horizontal integration is the most favourite strategy by the transport sub-industry (102 investments, i.e. $73 \%$ of the total FDI in transport activities), particularly by the road passenger transport firms (100\% of the total FDI per subindustry) and by the sea and air transport firms (respectively, $84 \%$ and $83 \%$ of the total FDI per sub-industry). Also the $95 \%$ of the total FDI made by couriers is horizontal (Fig. 3).

The integration strategies are driven by several motivations, as described in Section 2.2. As concerns the road passenger transport, the liberalisation process of the Italian industry and the consequent international calls for tender of urban or inter-urban transport services' supply, published by different Italian municipalities, have attracted some European foreign MNE. In particular, the English big operator Arriva International PLC has undertaken different acquisitions of Italian firms, mainly located in the North (especially,

\footnotetext{
${ }^{6}$ The vertical investments have been distinguished by the horizontal ones, using the 6-digit 2002 NACE classification of the economic activities. According to Hijzen et al. [24], the investments, which take place within the 4-digit industry, have been classified as horizontal FDI, while the investments across 4-digit industries have been classified as vertical. Nevertheless, the investments of the bigger 3PLs or 4PLs providers have been considered as horizontal, because these firms are multiproduct, i.e. they offer a large number of different services both in their country of origin and in the countries of destination.
}

Lombardy, Piedmont and Friuli-Venezia Giulia). Arriva is the first multinational company in terms of number of FDI on the total inward investments in the Italian logistics industry $(5 \%$ on the total Italian FDI and $22 \%$ of the Italian investments made by the first ten global players ${ }^{7}$ [27]). In this sector, the main motivation driving integrations is the aim to reinforce the market power in the European countries, taking advantage from the change of the regulation in specific country such as Italy. The efficiency considerations do not hold for this industry, because the production of the services is local based (i.e., it is impossible to use the same buses or infrastructure both in the London public transport and in the Milan urban area).

Similarly, within the boundaries set by the antitrust legislation, the liberalisation of the postal activities has caused an increasing concentration process of the couriers in a small number of operators, pushed by competitive and efficiency considerations: the two bigger ones in Europe-the Dutch TNT Post Group (TPG) and the German Deutsche Posthave penetrated the Italian market, realising respectively the $14 \%$ and the $6 \%$ of the first ten global players' total inward FDI. The European Post Offices have undertaken the most aggressive diversification strategies, in order to increase their geographic coverage, develop efficient IT systems and achieve high brand awareness [6] and to defend their market share from the American couriers such as UPS and Federal Express.

As concerns the horizontal investments in the maritime ${ }^{8}$ and airline industries, they also reflect the growing concentration process, which in the last decades has

\footnotetext{
${ }^{7}$ The first ten global players are: Arriva International, Apollo Global Management, Eurokai, TNT, 3I Group, Deutsche Bahn, Deutsche Post, Interprogramme Holding, A.P. Moller-Maersk, Kuwait Petroleum [for a review, see 27].

${ }^{8}$ According to LogINT, the two bigger maritime companies, in terms of number of inward FDI over the total, are the German Eurokai KG and the Danish A.P. Moller-Maersk.
} 
Fig. 2 Distribution of the different integration typologies in logistics industry

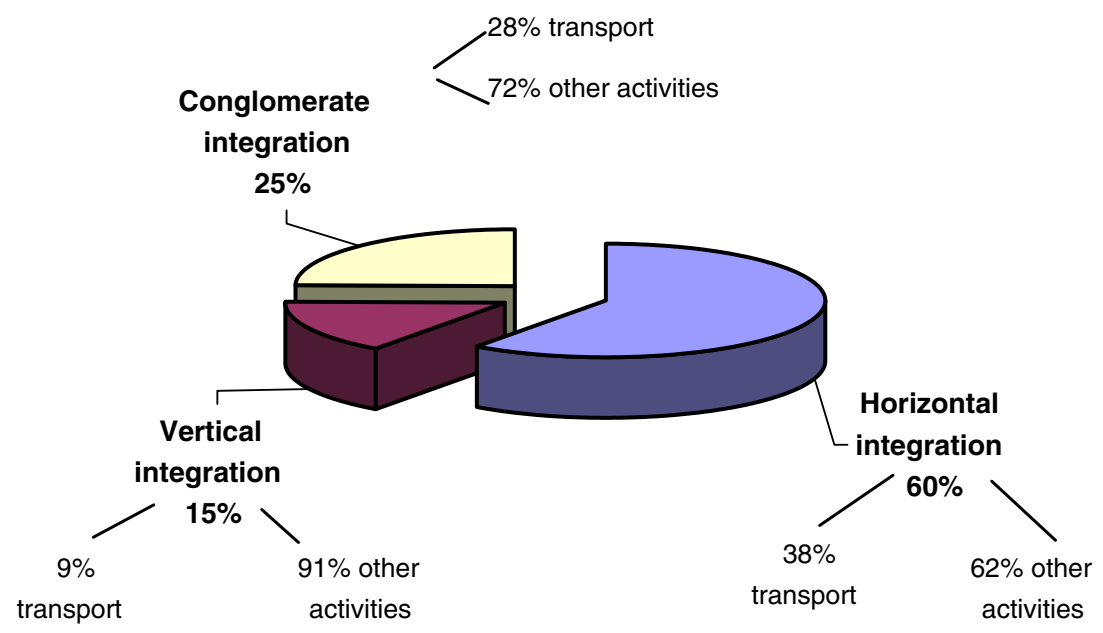

characterised the global market, allowing the participating firms to reap benefits of scale, competitive advantages [12, $31,32]$ and a sufficient size to cope with the high investments in physical and ICT infrastructure to operate efficiently [6]. In fact, in these sub-industries the rate of fixed costs over the total is particularly high.

Moreover, in the transport and couriers sub-industries, it is possible to identify another key driver of horizontal integration: the creation of efficient transport chains able to control the main traffic flows and guarantee a wider geographic coverage [6, 34].

The analysis referring to the horizontal integration allows to partially confirm the hypotheses described in Section 2.2: the competitive considerations and the research of scale economies are extremely relevant motivations for all the sub-industries ((c) in Table 4), with one exception: the "economies of scale", which do not hold for companies investing in the urban public transport ((a) in Table 4). Regulation also seems to be extremely relevant in different sectors, such as road passenger transport and couriers. Besides, no information permits to test the "access to technologies" motivation.

As concerns vertical integrations, almost all investments (91\%) refer to the 63 NACE sub-industry ("supporting and auxiliary transport activities of travel agencies") (Fig. 2), particularly the forwarders (41\%-Fig. 3); they have mainly been undertaken by maritime MNE (44\%) and railways investors $(13 \%)$.

The vertical integration allows the investing firms to diversify their product, extending the number of supplied services through three different ways: (a) by completing the transport chain, in order to offer door-to-door links to the
Fig. 3 Type of integrations in the different logistics sub-industries (\% over total sub-industry FDI)

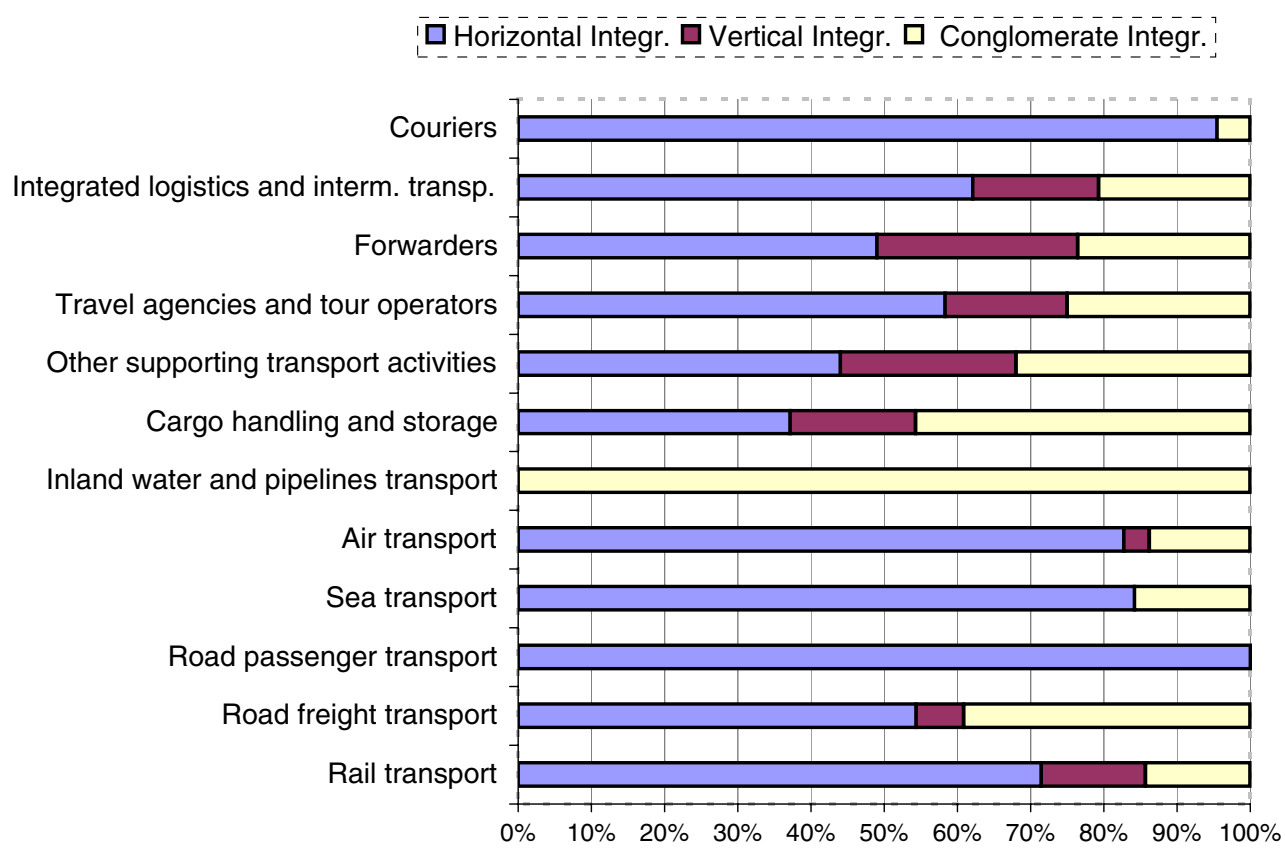


clients; (b) by integrating different logistics services along the supply chain; (c) by supplying auxiliary and complementary activities with respect to the core service.

Only few cases of integration refer to the first type (a), i.e. within two firms of different transport sub-industries. A significant example is given by the investments of Eurokai in Sogemar and Hannibal ${ }^{9}$, two companies offering intermodal (rail-road) transport. The main motivation can be found, from one hand, in cutting transaction cost as well as controlling the level of service along the entire transport chain (i.e. in terms of reliability and speed), from the other hand, in satisfying the growing customers' need to have a complete transport service from origin to destination. In this way, the transport providers reinforce or perhaps defend their market share and try to control the main traffic flows, reaching economies of scale and scope.

A vertical integration of the second type (b) takes place within firms of the 63 NACE sub-industry, for example offering storage activities, and firms of the transport subindustry. This integration type aims at supplying a complete range of logistics activities and providing new value-added services in an integrated package, along the supply chain [29]. This is the strategy adopted by the MNE, which aim at becoming integrated logistics service providers (3PLs or 4PLs), by acquiring specialist capabilities. The investments of this type are mainly concentrated in the cargo handling and storage sub-industry (NACE 63.1) or in the forwarding activities (NACE 63.40.1). Many operators, such as the forwarder Kuehne \& Nagel or the courier Deutsche Post have evolved, by M\&A, in integrated logistics providers. An increasing level of functional integration permits to cut many transaction costs and to response to manufacturing demand looking for global logistics package rather than single function (transport or storage) services, thus increasing market share.

The majority of the FDI belonging to vertical integrations has been made at the end of Nineties and the beginning of 2000; in 2002 a downturn has began [6]. This is the reason why in the period of analysis of the present paper (2000-2008) the vertical investments only account for the $15 \%$ over the total.

The third category of the vertical integration (c) is more diversified. It includes: (c1) investments in the handling activities realised by airline or shipping companies or by terminal operators; (c2) FDI of the shipping companies in terminals; (c3) investments of single transport mode operators in specialised agencies (e.g., in sea or air transport). The first two investments typologies $(\mathrm{c} 1, \mathrm{c} 2)$ are mainly motivated by the search of economies of scale and scope, but also by the

\footnotetext{
${ }^{9}$ Specifically, Eurokai has the control of the Italian Group Contship Spa, Sogemar and Hannibal companies belong to.
}

transaction costs' reduction in the backward relations along the logistics supply chain. For example, due to the shortage of working capital, in the maritime chain several shipping companies have invested their capital in terminals [34], dedicated to their own activity (e.g. Cosco Pacific) or to different operators' activities (multi-user terminals) in order to improve the utilisation rate (e.g. the above cited A.P. Moller-Maersk). Instead, the investments of the transport operators in agencies (c3) mainly aim at eliminating transaction costs, in the services' distribution (forward integration along the supply chain).

The analysis of the vertical integration strategies allow to test the majority of the hypotheses with the exception of "regulation" and "access to technologies" (Table 4). Specifically, the three vertical integration's categories $(a, b, c)$ are driven by the need to satisfy the customers' needs and so reinforce or defend the market share; therefore, we can assign (c) instead (b) to the competitive considerations. The diversification also allows to achieve economies of scope and remove transaction costs (the (c) in Table 2 are confirmed), but even scale economies can be reaped by controlling traffic flows along the logistics chain (they are indicated as relevant in Table 4).

The third integration strategy (conglomerate integration) in the last years is spreading both in Italy and in the global scenario. According to Federtrasporto-Nomisma [15], the FDI undertaken by financial investors or firms belonging to other industries have grown $12.6 \%$ in $2005,20.6 \%$ in 2006 and $23 \%$ in 2007 . As table 3 clearly shows, the conglomerate investments are made firstly by financial and real estate intermediaries ( $43 \%$ ), followed by the manufacturing industry ( $24 \%$, i.e. $10 \%$ food and agriculture, $5.5 \%$ metal, machinery and electric goods, $4.5 \%$ transport equipment, $3 \%$ chemical products and $1 \%$ publishing), the extraction, production and distribution of petroleum, gas and other forms of energy $(17 \%)$, wholesale and retail trade (7\%), building industry (3\%) and finally business services $(6 \%)$. The investors of other industries concentrate their FDI (72\%) in activities different from the pure transport, which offer higher value added services (e.g. forwarding activities-22\% -, cargo handling and storage $-15 \%$-, other supporting transport activities$15 \%$ - and integrated logistics and intermodal transport$11 \%)$. Within the transport activities, road freight transport is preferred (17\%).

The large investments carried out by the financial and real estate intermediaries indicate that logistics is considered as a profitable industry in terms of capital return; thus, the analysis suggests to add a third specific motivation within the category "other considerations" (last row in Table 4).

Several financial intermediate operators directly control big logistics groups; as a consequence, many of their investments should be considered vertical or horizontal. For example, the financial American Apollo Global Manage- 
Table 3 Conglomerate integration (CI) by different sub-industries

\begin{tabular}{|c|c|c|c|c|c|c|c|c|}
\hline Logistics sub-industries & $\begin{array}{l}\text { Financ. \& real } \\
\text { estate interm. }\end{array}$ & $\begin{array}{l}\text { Extrac., produc., } \\
\text { distrib. energy }\end{array}$ & $\begin{array}{l}\text { Food \& } \\
\text { agric. Prod. }\end{array}$ & $\begin{array}{l}\text { Other } \\
\text { manuf. } \\
\text { prod. }\end{array}$ & $\begin{array}{l}\text { Wholesale, retail } \\
\text { \& construct. }\end{array}$ & Business services & $\begin{array}{l}\text { Total } \\
\text { CI }\end{array}$ & $\begin{array}{l}\% \text { on } \\
\text { total CI }\end{array}$ \\
\hline Rail transport & 1 & & & 1 & & & 2 & $2 \%$ \\
\hline Road freight transport & 8 & 5 & 2 & & 3 & & 18 & $17 \%$ \\
\hline Sea transport & 0 & 1 & 1 & & & 1 & 3 & $3 \%$ \\
\hline Air transport & 3 & & & 1 & & & 4 & $4 \%$ \\
\hline $\begin{array}{l}\text { Inland water and } \\
\text { pipelines transport }\end{array}$ & 1 & 2 & 1 & & & & 4 & $4 \%$ \\
\hline Total transport activ. & 13 & 8 & 4 & 2 & 3 & 1 & 31 & $28 \%$ \\
\hline $\begin{array}{l}\text { Cargo handling and } \\
\text { storage }\end{array}$ & 3 & 6 & 2 & 2 & 1 & 2 & 16 & $15 \%$ \\
\hline $\begin{array}{l}\text { Other supporting } \\
\text { transport activities }\end{array}$ & 6 & 2 & 2 & 2 & 2 & 2 & 16 & $15 \%$ \\
\hline $\begin{array}{l}\text { Travel agencies and } \\
\text { tour operators }\end{array}$ & 4 & & & 1 & 3 & 1 & 9 & $8 \%$ \\
\hline Forwarders & 15 & & 1 & 6 & 1 & 1 & 24 & $22 \%$ \\
\hline $\begin{array}{l}\text { Integrated logistics, } \\
\text { intermodal transport }\end{array}$ & 5 & 2 & 2 & 2 & 1 & & 12 & $11 \%$ \\
\hline Couriers & 1 & & & & & & 1 & $1 \%$ \\
\hline Total other activ. & 34 & 10 & 7 & 13 & 8 & 6 & 78 & $72 \%$ \\
\hline Total logistics industry & 47 & 18 & 11 & 15 & 11 & 7 & 109 & $100 \%$ \\
\hline$\%$ on total industry & $43 \%$ & $17 \%$ & $10 \%$ & $14 \%$ & $10 \%$ & $6 \%$ & $100 \%$ & \\
\hline
\end{tabular}

ment has acquired the logistics branch of TNT, calling it Ceva Logistics. Ceva Logistics in 2007 has invested its capital in the international forwarder EGL and in 2008 has acquired Spedimacc, a technical courier, specialised in fragile and valuable goods' transport and handling, and Transitalia, operating in the publishing distribution. These two acquisitions have been undertaken to strengthen Ceva's presence in the country and, as concerns publishing distribution, to reach the $20 \%$ of the Italian market [16]. If we associate these three investments to the parent company itself (Apollo Global Management), they might be classified as conglomerate, but if we associate them to

Table 4 Results of the empirical analysis

\begin{tabular}{|c|c|c|c|c|c|c|}
\hline \multirow[t]{3}{*}{ Motivation } & \multicolumn{6}{|c|}{ Integration strategies } \\
\hline & \multicolumn{2}{|l|}{ Horizontal } & \multicolumn{2}{|l|}{ Vertical } & \multicolumn{2}{|c|}{ Conglomerate } \\
\hline & Hypothesis & Results & Hypothesis & Results & Hypothesis & Results \\
\hline \multicolumn{7}{|l|}{ Competitive considerations } \\
\hline 1a) Increasing market or political power & $\mathrm{c}$ & $\mathrm{c}$ & $\mathrm{b}$ & $\mathrm{c}$ & a & a \\
\hline 1b) Defending market share & $\mathrm{c}$ & $\mathrm{c}$ & $\mathrm{b}$ & $\mathrm{c}$ & a & n.t. \\
\hline \multicolumn{7}{|l|}{ Efficiency considerations } \\
\hline 2a) Economies of scale & $\mathrm{c}$ & $\mathrm{c} / \mathrm{a}(1)$ & a & $\mathrm{b}$ & a & $\mathrm{b}$ \\
\hline 2b) Economies of scope & a & a & $\mathrm{c}$ & $\mathrm{c}$ & a & a \\
\hline 2c) Elimination of transaction costs & a & a & $\mathrm{c}$ & $\mathrm{c}$ & a & $\mathrm{b}$ \\
\hline \multicolumn{7}{|l|}{ Other considerations } \\
\hline 3a) Regulation & $\mathrm{b}$ & $\mathrm{c}$ & $\mathrm{b}$ & n.t. & a & n.t. \\
\hline 3b) Access to technologies & $\mathrm{c}$ & n.t. & $\mathrm{b}$ & n.t. & $\mathrm{b}$ & n.t. \\
\hline 3c) High capital return & & a & & a & & $\mathrm{c}$ \\
\hline
\end{tabular}

${ }^{\mathrm{a}}$ not relevant; ${ }^{\mathrm{b}}$ relevant; ${ }^{\mathrm{c}}$ extremely relevant; n.t.: not tested; (1) not relevant for urban public transport 
Fig. 4 Type of integration by area of origin of the FDI

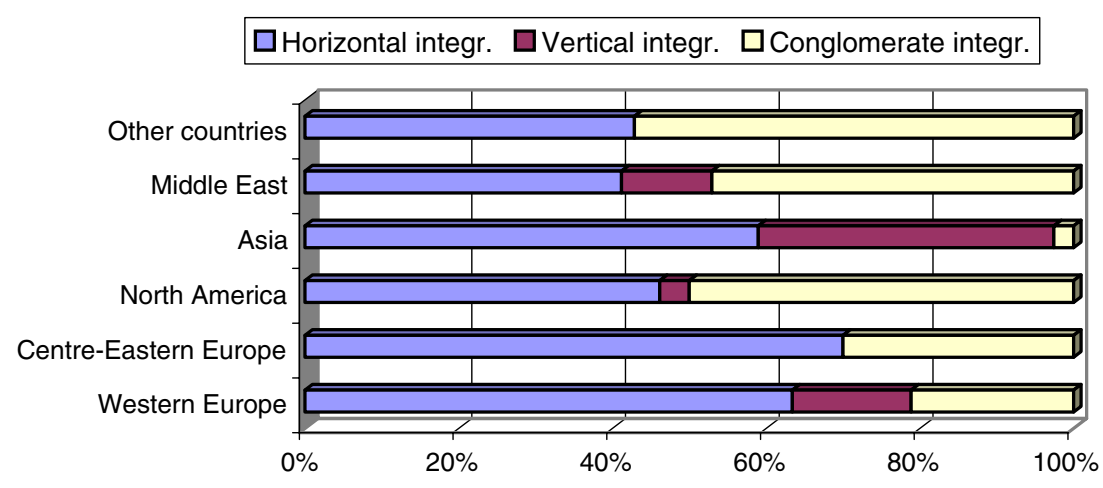

the secondary group (Ceva Logistics), they are vertical. In the present paper, we follow the standard classification adopted in the literature, therefore, we consider these investments as conglomerate integrations.

Two other important global financial players, operating in the Italian logistics market, are: the English 3I Group PLC, which controls the Italian forwarder Saima Avandero and the Italian divisions of the Belgium ABX Logistics; and Interprogramme Holding of Luxembourg, which has acquired different air companies (e.g. Meridiana and Eurofly) and has a minority participation in the Florence Airport.

As concerns the energy extraction, production and distribution industry, the bigger MNE operating in the Italian logistics industry is Kuwait Petroleum, which has invested in different freight road transport and cargo handling and storage firms, probably in order to better control the management of its products' flows, to reach scale benefits and to reduce transaction costs.

The investments in transport or other activities, undertaken by the manufacturing firms, are often the result of a spin-off of their internal logistics division, which is generally motivated by the search of scale economies, while maintaining, at the same time, the control on the logistics function. For example, the French PSA-Peugeot Citroen has created the operator GEFCO (Les Groupages Express de Franche Compté), specialised in the logistics activities for the automobile industry. The Swedish Electrolux controls Electrolux Logistics Italy SpA and other firms, which offer forwarding and handling and storage activities; within the food industry two German MNE (Dr. August Oetker Kg and Theobald Mueller Ag) and the Switzerland Nestlè have made several investments mainly in the NACE 63 industry but also in maritime and road freight transport.

The analysis on the conglomerate integrations shows that the majority of the hypotheses are tested with the exception of "defensive strategy", "regulation" and "access to technologies" (Table 4). According to the analysis, however, when a manufacturing or energy firm undertakes an investment in the logistics industry the efficiency considerations, in terms of scale economies and transaction costs' reduction, play a relevant role ((b) instead of (a) in Table 4).

\subsection{Integration strategies by investment area of origin and destination}

The analysis of origin and destination areas underlines that the horizontal strategy is the first choice of all the European and Asian MNE, while the conglomerate integration is preferred by the MNE located in North America, Middle East and other countries; finally, the vertical integration is the second choice of the Asian FDI (38\%; Fig. 4). Specifically, European MNE invest in Italy through horizontal integrations to consolidate and defend their market power and reach scale economies, trying to become European Champions, i.e. "big European companies that have successfully understood the advantages (scale and free-flow of production factors) of operating in the
Fig. 5 Type of integration by area of destination of the FDI

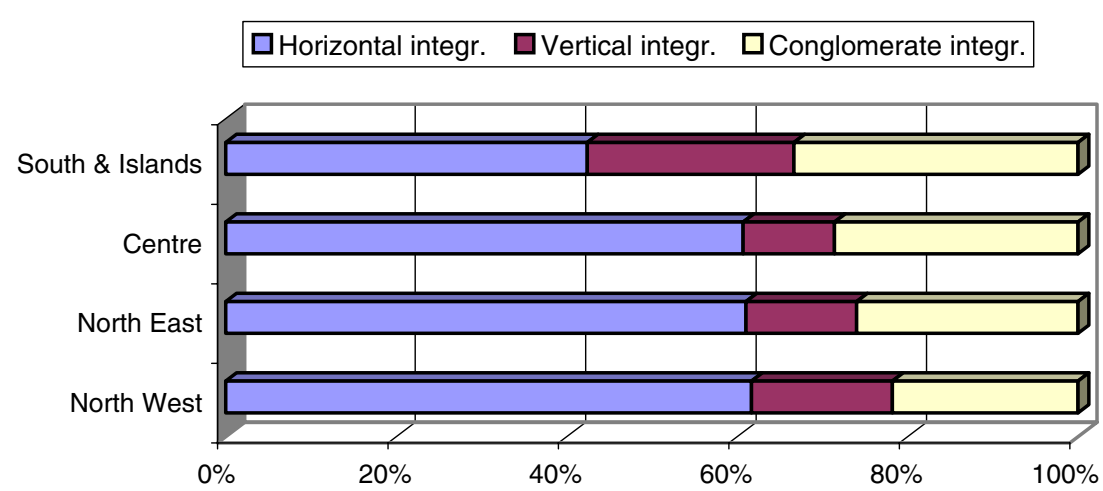


Single Market environment" within the European Union [28]. Asian investors undertake FDI to penetrate into the European market, firstly for selling their core product through horizontal integration, and secondly for extending their supply through vertical integration. Besides, the Italian logistics market is seen a profitable investment area for MNE coming from USA, Middle East and other countries.

As concerns Italy as destination, about the $60 \%$ of FDI, located in the North West, North East and Centre, is horizontal, while the share of conglomerate and vertical strategies is higher in South and Islands with respect to the other areas (Fig. 5).

In the Centre-North, where the logistics firms tend to concentrate their activity, the FDI are mainly motivated by competitive and economies of scale considerations. Instead, in the remaining part of Italy the main feasible determinants of the vertical investments are the economies of scope and the transaction costs' reduction, while production diversification in case of conglomerate integration.

\section{Conclusions}

The global economy is the driver of the growing internationalisation process, which interests the Italian logistics market. The significant fragmentation of the national logistics service supply in a high number of SME, characterised by a lack of human and financial resources and mainly offering low value-added and not integrated activities, has promoted the entry of foreign MNE.

The present paper focuses on the integration strategies (horizontal, vertical and conglomerate), associated with inward FDI (greenfield and brownfield investments) and aims at understanding the motivations driving them. In doing so, the paper extends the existing literature, which mainly focuses on the manufacturing sector and, as far as logistics is concerned, mainly investigates horizontal M\&A.

Reflecting a global trend, inward FDI in Italy are concentrated in the same parent MNE's logistics subindustry (horizontal integration) and specifically in those sectors that, in the last decade, have been involved in regulation rules' changes (liberalisation of the road passenger transport, courier and postal activities) and which present a high rate of fixed costs (e.g. maritime and air transport). The main motivations behind horizontal strategies are found in: increasing and defending market, reaching economies of scale and regulation.

Different determinants drive vertical integrations but, behind all, the extension of the number of supplied services allows to reach competitive advantages, economies of scale and scope and to cut transaction costs.
As concerns the conglomerate integration, the financial and real estate investors consider logistics, and mainly the higher value-added services, a profitable industry for the capital return; nevertheless, the logistics industry also attracts several manufacturing and energy firms, which aim at improving the efficiency of their products' handling, while maintaining the control over logistics operations. The determinants of conglomerate investments can be found in: reaching economies of scale and transaction costs' decreasing, especially when the integrations are the result of the outsourcing of logistics activities previously carried out within the firm.

The empirical analysis has, nevertheless, showed that the motivations driving the investments choices are often multiple and they differ according to the peculiarities of the analysed sub-industry. In fact, some motivations, which are extremely relevant in some sub-sectors can not be relevant in other sub-sectors. Thus, there is a need for a more detailed investigation, through direct interviews, together with a quantitative analysis (econometric model).

Specifically, further research efforts can be very useful in order to (i) evaluate the impact of the different integration strategies both on the Italian logistics industry and, more generally, on the Italian economic competitiveness; (ii) predict future scenarios, with reference to the feasible different developments of the logistics providers and their customers' needs; (iii) frame appropriate policies.

However, the present analysis already allows to draw some considerations on the impact of inwards FDI on the logistics industry. Italy, thanks to its barycentre position, is clearly an interesting market where foreign players may consolidate their market power, while rising efficiency improvements for their core products. This phenomenon might induce two main effects of opposite sign, which interest the policy makers' debate. A negative effect consists of the progressive closing down of several Italian small enterprises, which are acquired by the international big players. On the other hand, a positive impact may be associated to the entrance of external capital that can help the logistics providers in finding the financial resources, which are needed to innovate and improve the business. Besides, the Italian manufacturing firms can be advantaged by a more efficient logistics industry, if it is reflected in the price of services, supplied by the logistics providers. The creation of integrated services' package, through vertical investments, makes the logistics supply more effective with clear benefits for the demand.

Open Access This article is distributed under the terms of the Creative Commons Attribution Noncommercial License which permits any noncommercial use, distribution, and reproduction in any medium, provided the original author(s) and source are credited. 


\section{References}

1. Agarwal S, Ramaswami S (1992) Choice of foreign entry mode: impact of ownership, location, and internationalization factors. J Int Bus Stud 23:1-27

2. Anderson E, Gatignon H (1986) Modes of foreign entry: a transaction cost analysis and proposition. J Int Bus Stud 17:1-16

3. Barba Navaretti G, Venables AJ (2004) Multinational firms in the world economy. Princeton University Press

4. Brouwer A, Mariotti I (2009) Eterogeneità delle imprese e performance economica. Il caso del settore logistico in Italia. In: Marletto G, Musso E (eds) Trasporti, ambiente e Territorio. La ricerca di un nuovo equilibrio, Franco Angeli, Milano, pp. 251-258

5. Buckley P, Casson M (1976) The future of the multinational enterprise. Homles \& Meier, New York

6. Carbone V, Stone MA (2005) Growth and relational strategies used by the European logistics service providers: rationale and outcomes. Transp Res Part A 41:495-510

7. Chang SJ, Rosenzweig PM (2001) The choice of entry mode in sequential foreign direct investment. Strateg Manage J 22(8):747-776

8. Cooper J, Browne M, Peters M (1991) European logistics, markets, management and strategy. Blackwell, Oxford

9. Cruijssen F, Martine Cools M, Dullaert W (2007) Horizontal cooperation in logistics: opportunities and impediments. Transp Res Part A 43:129-142

10. Dörrenbächer C (2003) Corporate reorganisation in the European transport and logistic sector in the 1990s: diversification, internationalisation and integration. Lit, Münster

11. Dunning J (1988) Explaining international production. Unwin Hyman, London

12. Fan T, Vigeant-Langlois L, Geissler C, Bosler B, Wilmking J (2001) Evolution of global airline strategic alliance and consolidation in the twenty-first century. J Air Transp Manag 7(6):349-360

13. Federtrasporto-Nomisma (2006) Scenari dei trasporti. L'internazionalizzazione del trasporto: la posizione dell'impresa italiana. Quaderno n. 8, Rome

14. Federtrasporto-Nomisma (2007) Scenari dei trasporti. L'internazionalizzazione del trasporto: la posizione dell'impresa italiana. Quaderno n. 9, Rome

15. Federtrasporto-Nomisma (2008) Scenari dei trasporti. L'internazionalizzazione del trasporto: la posizione dell'impresa italiana. Quaderno n. 10, Rome

16. Federtrasporto-Nomisma (2009) Scenari dei trasporti. L'internazionalizzazione del trasporto: la posizione dell'impresa italiana. Quaderno n. 11, Rome

17. Girma S (2002) The process of European integration and the determinants of entry by non-EU multinationals in UK manufacturing. Manch Sch 70(3):315-335

18. Goldman E, Gorton G (2000) The visible hand, the invisible hand and efficiency, Working paper 05, Wharton Financial Institution Center
19. Gorton G, Kahl M, Rosen R (1998) Eat or Be Eaten: a theory of mergers and merger waves mimeo, University of Pennsylvania

20. Gunasekaran A, Ngai E (2004) Information systems in supply chain integration and management. Eur J Oper Res 159(2):269295

21. Häkkinen L, Norrman A, Himola OP, Ojala L (2004) Logistics integration in horizontal mergers and acquisitions. Int $\mathrm{J}$ Logist Manag 15(1):27-42

22. Haleblian J, Finkelstein S (1999) The influence of organisational acquisition experience on acquisition performance: a behavioural learning perspective. Adm Sci Q 44(1):29-56

23. Hennart JF (1982) The theory of the multinational enterprise. University of Michigan Press, Ann Arbor

24. Hijzen A, Görg H, Manchin M (2008) Cross-border mergers \& acquisitions and the role of trade costs. Eur Econ Rev 52:849866

25. Kim WC, Hwang P (1992) Global strategy and multinationals' entry mode choice. J Int Bus Stud 23:29-53

26. Kogut B (1988) Joint ventures: theoretical and empirical perspectives. Strateg Manage J 9:319-332

27. Maggi E, Mariotti I (2009) Le multinazionali logistiche estere in Italia: determinanti, strategie e impatti. In: Borri D, Ferlaino $\mathrm{F}$ (eds) Crescita e sviluppo regionale: strumenti, sistemi, azioni. Franco Angeli, Milano, 239-257

28. Mosconi F (2008) L'economia dell'Unione e i suoi campioni. Il Mulino 2(2008):309-322

29. Notteboom T (2007) Strategic challenges to container ports in a changing market environment. Devolution, port governance and port performance. Res Transp Econ 17:29-52

30. Ojala L (1993) Changing logistics patterns and policies in Northern Europe. Int J Logist Manag 4(2):25-40

31. Oum T, Park JH, Kim K, Yu C (2002) The effect of horizontal alliances on firm productivity and profitability: evidence from the global airline industry. J Bus Res 854:1-10

32. Shepperd E, Seidman D (2001) Ocean shipping alliances: the wave of the future. I J Marit Econ 3(4):351-367

33. UNCTAD (2006) World investment report 2006-FDI from developing and transition economies: implications for development. United Nations, Geneva

34. Van de Voorde E, Vanelslander T (2009) Market power and vertical and horizontal integration in the maritime shipping and port industry. Discussion Paper 2009-2, Joint Transport Research Centre, OECD, International Transport Forum

35. Veugelers R (2002) M\&A and R\&D: A Literature Review. In: Consult I (ed) Mergers and acquisitions and science and technology policy. Idea Consult, Brussels

36. Wall S, Bronwen R (2001) Introduction to international business. Pearson Education, Malaysia

37. Wei Y, Liu X, Liu B (2004) Entry modes of foreign direct investment in China: a multinomial logit approach. Working Paper 1, Lancaster University Management School, Lancaster 